\title{
New fire retardant compositions for fire-resistant automatic curtains
}

\author{
Maria Nikitina ${ }^{1, *}$, Andrey Ustinov ${ }^{1,2}$, Viktoria Kiseleva ${ }^{1}$, and Igor Babikov ${ }^{1,2}$ \\ ${ }^{1}$ Peter the Great St. Petersburg Polytechnic University, Higher School of Technosphere Safety, 29 \\ Politekhnicheskaya st., St.Petersburg, 195251, Russia \\ 2“'Gefest” Enterprise group, 65A Serdobolskaya st., St. Petersburg, 197342, Russia
}

\begin{abstract}
The paper overviews the way by which intumescent fire retardant compositions act as fillers in fire-resistant automatic curtains. A several intumescent compositions, which form a heat-isolating charred layer when they are exposed to high temperatures, were produced and applied to the mineral-fabric basis of the curtain. Fire-protective properties of produced materials were assessed and compared with foreign specimens. Swelling coefficient and material's fire durability were considered as operating parameters. The developed specimen which performed the best during fire tests was sent to accredited laboratory. It was proven, using standardized methods, that it's fire resistance limit reaches 30 minutes. This proves an effective contribution of an intumescent compound and opens new ways of using them in fire curtains manufacturing.
\end{abstract}

\section{Introduction}

Fire is one of the most terrifying events that can happen in someone's life. Fires are also hazardous for natural and urban environments as they cause significant damage if not taken under control. In spite of all preventive actions, more than 300000 fires occur in Russia every year. Half of them occur in places where big amounts of people are concentrated which leads to a significant number of victims.

Nowadays one of the most effective ways to ensure fire safety of large buildings is to use fire-resistant automatic curtains; these are the constructions with standardized fire resistance limit. The main purpose of using fire-resistant curtains is to divide the rooms into separate fire compartments and prevent the spread of fire throughout the building, thereby protecting people and property from the effects of fire and smoke. If the ignition occurs, the alarm from a fire-preventive system launches the curtain's mechanism - it goes down and separates the source of ignition.

Creation of fire-resistand curtains with increased fire durability is a task of current interest, and in particular there is a big amount of researches which concentrate on using curtains with additions of thermally expanding materials. There is a great prospective of using such materials instead of traditional mineral fibers which sinter quite fast and lose their fire resistance. Fillers which can expand as a result of heating and endothermic reactions are a

* Corresponding author: angrymari@gmail.com 
subject of interest [1-3]. Vermiculite, perlite and oxidized graphite can be referred to such kind of materials. The purpose of current research is to develop an intumescent fire retardant composition for fire curtains [4-5].

Nowadays there can be found just a few types of fire-resistant curtains:

- quilted «sandwich-fabric» - two layers of reinforced fiberglass, the space between them is filled with mineral wadding;

- intumescent fabrics of the following types: external and internal; based on intercalated graphite and on an intumescent compound (including melamine, pentaerythritol and ammonium polyphosphate).

\section{Methods}

A several compositions for fire-resistant curtains have been developed (table 1). Hypothesis is that the charred layer which forms as a result of exposing an intumescent composition to high temperatures should increase the fire resistance limit of the curtain due to the charred layer's high thermal durability [6-19].

Table 1 - Recipes of intumescent compositions for fire-resistant curtains

\begin{tabular}{|c|c|c|c|c|}
\hline \multirow{2}{*}{ Component } & \multicolumn{4}{|c|}{ Quantity, \% } \\
\cline { 2 - 5 } & Specimen № 1 & Specimen № 2 & Specimen № 3 & $\begin{array}{c}\text { Specimen № } \\
\mathbf{4}\end{array}$ \\
\hline $\begin{array}{c}\text { Intercalated } \\
\text { graphite }\end{array}$ & 14 & 14 & 14 & 14 \\
\hline Vermiculite & 6 & 6 & 6 & 6 \\
\hline $\begin{array}{c}\text { Intumescent } \\
\text { composition }\end{array}$ & - & - & - & 30 \\
\hline Microspheres & - & - & 1 & - \\
\hline Dispersion & 80 & 80 & 79 & 50 \\
\hline Total: & 100 & 100 & 100 & 100 \\
\hline
\end{tabular}

An intumescent compound swells and increases in volume as a result of heating; swelling coefficient is used to measure the efficiency of a compound. To calculate the swelling coefficient, compositions were applied to the fiberglass grid with cell sizes $15 \times 7.5 \mathrm{~mm}$; thickness of dried layer must not exceed $1 \mathrm{~mm}$. The curtain's fire-protective properties were then assessed using methods from GOST 53307-2009.

The following materials were used as curtains basis: sandwhich-fabric, basaltic fiber, foil basaltic fiber and reinforced basaltic fiber.

Intumescent compounds were applied to one side of the curtain's basis or to both sides as it is shown in table 2 .

Table 2 - Specimens of developed fabrics

\begin{tabular}{|c|c|c|c|}
\hline $\begin{array}{c}\text { № of the } \\
\text { specimen }\end{array}$ & $\begin{array}{c}\text { Picture of the } \\
\text { specimen }\end{array}$ & Basis & $\begin{array}{c}\text { Way of fire retardant's } \\
\text { applying }\end{array}$ \\
\hline & & Fiberglass & Gluing of two fabrics \\
\hline 1 & & & \\
\hline
\end{tabular}




\begin{tabular}{|c|c|c|c|}
\hline 2 & b & Basaltic fiber & Gluing of two fabrics \\
\hline 3 & & $\begin{array}{l}\text { Foil basaltic } \\
\text { fiber }\end{array}$ & Gluing of two fabrics \\
\hline 4 & & Basaltic fiber & $\begin{array}{c}\text { Applying to both sides of } \\
\text { a fabric }\end{array}$ \\
\hline
\end{tabular}

Table 3 represents foreign and Russian commercial compositions which are commonly used in fire-resistant curtains. These compositions were considered as control samples in assessement of produced materials.

Table 3 - Specimens of commercial fabrics

\begin{tabular}{|c|c|c|c|}
\hline Specimen & $\begin{array}{l}\text { Picture of the } \\
\text { specimen }\end{array}$ & Basis & $\begin{array}{c}\text { Way of fire retardant's } \\
\text { applying }\end{array}$ \\
\hline $\begin{array}{c}A \\
\text { (Germany) }\end{array}$ & & Basaltic fiber & $\begin{array}{l}\text { Applying to both sides } \\
\text { of a fabric }\end{array}$ \\
\hline $\begin{array}{c}B \\
\text { (Germany) }\end{array}$ & & Basaltic fiber & Gluing of two fabrics \\
\hline $\begin{array}{c}C \\
\text { (China) }\end{array}$ & & Basaltic fiber & Gluing of two fabrics \\
\hline $\begin{array}{c}D \\
\text { (Russia) }\end{array}$ & & $\begin{array}{c}\text { Reinforced } \\
\text { basaltic fiber }\end{array}$ & $\begin{array}{l}\text { Mineral wool quilted } \\
\text { between fabrics }\end{array}$ \\
\hline
\end{tabular}

Due to the terms of manufacturing, fire-resistant curtains must undergo a few tests to assess their fire durability. Those tests are conducted according to methods of GOST 533072009 and some international standarts [20-24]; the tests are quite expensive and hard to perform, so within this research, initial comparative fire tests of specimens 1-4 and A-D were performed in a non-standardized laboratory; charred layer's thickness and specimen's behavior in flame were assessed. 
Specimens were applied to steel plates and were exposed to annealing in a furnace at $600^{\circ} \mathrm{C}$ for $5 \mathrm{~min}$ to assess their charring ability.

To assess the specimen's behavior while heating, it was adjusted vertically in a holder and was exposed to heating by flame from gas-burner till the temperature of side which wasn't exposing by flame exceeded $100^{\circ} \mathrm{C}$. The list of parameters such as presence of flame, smoke intensity, final thickness of a charred layer and rate of damage caused by fire were assessed.

\section{Results and discussion}

Specimen №1 has reached $97.1{ }^{\circ} \mathrm{C}$ on the non heating side. Charred layer crumbled and did not have enough adhesion to the surface (fig. 1). Smoke intensity was low and there were no molten drops falling from the specimen.

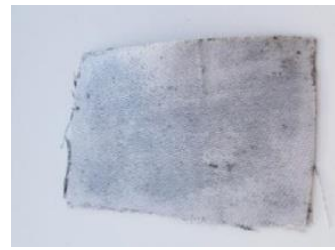

a)

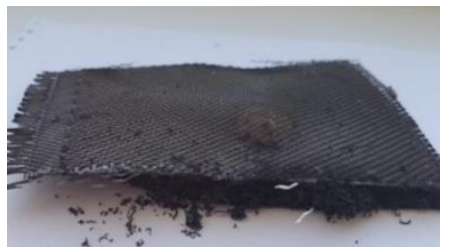

b)

Fig. 1. Pictures of specimen №1: $a$ ) before the fire test; $b$ ) after the fire test

Specimen №2 have been stable for $1 \mathrm{~min} 54 \mathrm{sec}$. Thickness of charred layer reached 1.5 sm (fig. 2). Smoke intensity was low and there were no molten drops falling from the specimen.

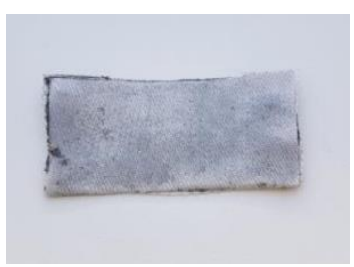

a)

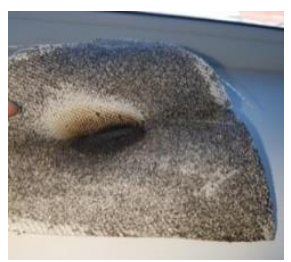

b)

Fig. 2. Pictures of specimen №2: $a$ ) before the fire test; $b$ ) after the fire test

Specimen №3 has reached $99{ }^{\circ} \mathrm{C}$ on the non heating side have been stable for 4 min. Thickness of charred layer reached $1.5 \mathrm{sm}$ (fig. 3). Smoke intensity was low and there were no molten drops falling from the specimen.

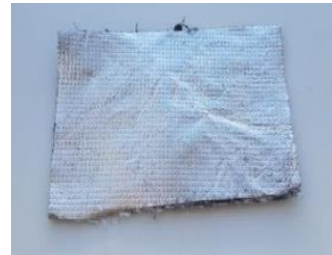

a)

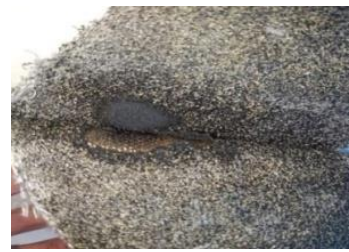

b)

Fig. 3. Pictures of specimen №3: $a$ ) before the fire test; $b$ ) after the fire test

Specimen №4 has shown better results than others in a row (fig. 4). Charred layer has had enough adhesion to the substrate due to addition of intumescent compound. Charred layer's thickness reached $2.7 \mathrm{sm}$. Smoke intensity was low and there were no molten drops falling from the specimen. 


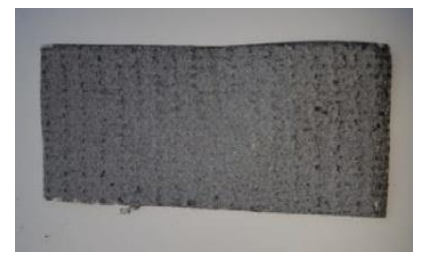

a)

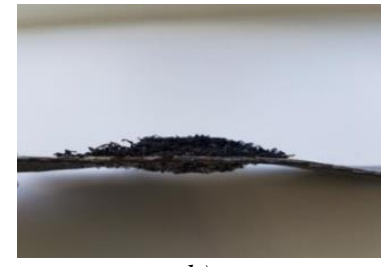

b)

Fig. 4. Pictures of specimen №4: $a$ ) before the fire test; $b$ ) after the fire test

Specimen's $A$ heating process started at $20^{\circ} \mathrm{C}$, and it smoothly grown to $50{ }^{\circ} \mathrm{C}$. Specimen's properties started to degrade quite fast on the initial stage of heating. Total time of heat exposure was $6 \mathrm{~min} 59 \mathrm{sec}$, charred layer thickness reached $2.5 \mathrm{sm}$, swollen graphite layer was falling down from the fabric (fig. 5). Smoke intensity was moderate, and there were no molten drops falling from the specimen.

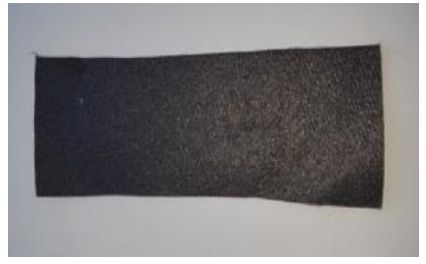

a)

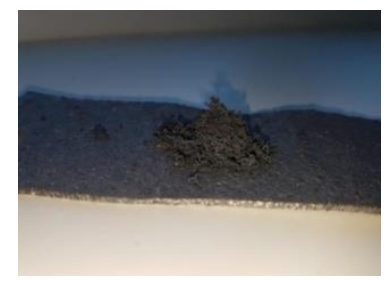

b)

Fig. 5. Pictures of specimen $A: a$ ) before the fire test; $b$ ) after the fire test

Specimen's $B$ heating process started at $20^{\circ} \mathrm{C}$, and it smoothly grown to $95^{\circ} \mathrm{C}$. Specimen's properties started to degrade quite fast on the initial stage of heating. Total time of heat exposure was $10 \mathrm{~min}$, charred layer thickness reached $1 \mathrm{sm}$, swollen graphite layer was falling down from the fabric (fig. 6). Smoke intensity was moderate, and there were no molten drops falling from the specimen.

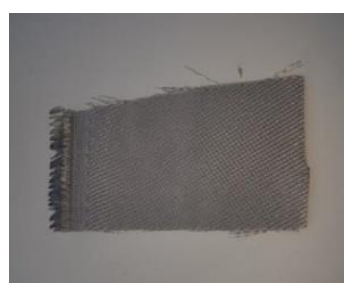

a)

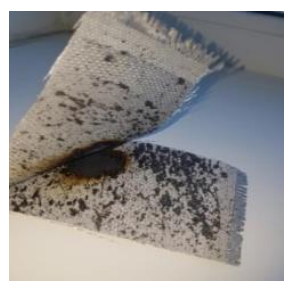

b)

Fig. 6. Pictures of specimen $B: a$ ) before the fire test; $b$ ) after the fire test

Specimen's $C$ heating process started at $20^{\circ} \mathrm{C}$, and it smoothly grown to $99^{\circ} \mathrm{C}$. Specimen's properties started to degrade quite fast on the initial stage of heating. Total time of heat exposure was $44 \mathrm{~min}$, charred layer started to smoke (fig. 7). Charred layer thickness was quite low and did not exceeded $0.5 \mathrm{sm}$. Smoke intensity was high, and there were no molten drops falling from the specimen.

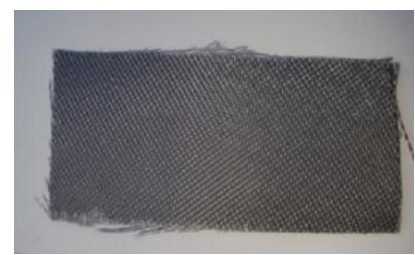

a)

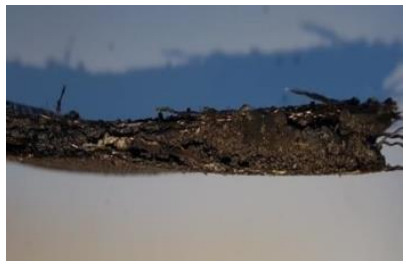

b)

Fig. 7. Pictures of specimen $C: a$ ) before the fire test; $b$ ) after the fire test 
The time which was needed for specimen $D$ to reach $71.5{ }^{\circ} \mathrm{C}$ was $15 \min 41 \mathrm{sec}$. No swelling was detected as specimen $D$ was filled with mineral fiber which doesn't swell. Specimen $D$ showed the highest fire resistant limit (fig. 8). There were no smoke or molten drops detected. According to the results of fire tests, specimen D (quilted) shown the highest thermal stability, fire resistant limit and the lowest smoke intensity.

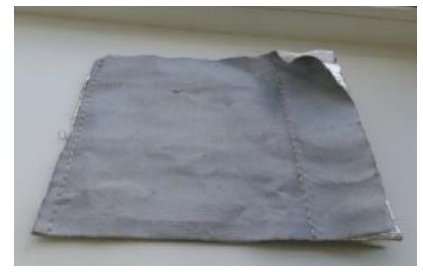

a)

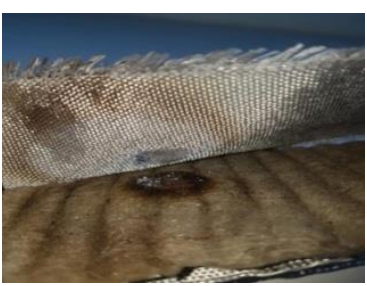

b)

Fig. 8. Pictures of specimen $D: a$ ) before the fire test; $b$ ) after the fire test

Table 4 represents all collected data of conducted experiments.

Table 4 - Experimental data on all studied specimens

\begin{tabular}{|c|c|c|c|c|c|}
\hline Specimen & $\begin{array}{c}\text { Critical } \\
\text { temperature, } \mathbf{C}\end{array}$ & $\begin{array}{c}\text { Time of } \\
\text { reaching } \\
\text { critical } \\
\text { temperature }\end{array}$ & $\begin{array}{c}\text { Charred } \\
\text { layer's } \\
\text { thickness, } \\
\text { sm }\end{array}$ & $\begin{array}{c}\text { Smoke } \\
\text { intensity }\end{array}$ & $\begin{array}{c}\text { Formation } \\
\text { of molten } \\
\text { drops }\end{array}$ \\
\hline 1 & 97.1 & $1 \mathrm{~min} 40 \mathrm{sec}$ & - & Low & - \\
\hline 2 & 98.3 & $1 \mathrm{~min} 54 \mathrm{sec}$ & 1.5 & Low & - \\
\hline 3 & 99 & $4 \mathrm{~min}$ & 1.5 & Low & - \\
\hline 4 & 99.1 & $6 \mathrm{~min}$ & 2.7 & Low & - \\
\hline$A$ & 50 & $6 \mathrm{~min} 59 \mathrm{sec}$ & 2.5 & Moderate & - \\
\hline$B$ & 95 & $10 \mathrm{~min}$ & 1 & Moderate & - \\
\hline$C$ & 99 & 44 & 0.5 & High & - \\
\hline$D$ & 71.5 & $15 \mathrm{~min} 41 \mathrm{sec}$ & - & - & - \\
\hline
\end{tabular}

In general, specimens №1, 2 and 3 have shown moderate results with specimen 1 having the lowest thermal stability and the worst charred layer's condition. This may be explained by low cohesive powers between graphite particles. So it is suggested to modify graphites by cohesive agents.

Foreign gluing fabrics are quite commonly used in fire-resistant curtains, but according to conducted tests their characteristics came to be quite low. An intumescent compound turns out to be locked between two layers, it has no enough space to fully expand. In this case fabrics which have an intumescent compound applied externally perform the best, as there are no obstacles for the compound to expand. Though specimen $A$ which has only intercalated graphite as a filler performed badly as graphite layer crumbled.

Specimen №4 performed well in this comparative study so it was decided to send it to the standardized laboratory. Due to the results of standardized fire tests, its fire resistance limit has reached $30 \mathrm{~min}$ which is equal to some commercial curtains. 


\section{Conclusions}

The results of conducted research allow to state that usage of intumescent compounds as fillers in fire-resistant curtains proves effective. Specimen №4 which has an intumescent compound as a filler showed increase in thermal stability (by $215 \%$ comparing with specimen №1); also its charred layer's thickness is significantly higher, which means that specimen with an intumescent filler will operate more effective in case of fire.

Fibers which are presented on a market and are commonly used in fire-resistant curtains manufacturing show moderate results, but their thermal stability is proven to be high. In general, their assessed properties are equal to those stated by manufacturers, although some of commercial specimens show moderate-high smoke intensity, what can not be said in relation of fabrics produced during the research.

This research is a step forward to replacing traditional components of fire-resistant curtains on intumescent compounds which are more flexible in using

\section{References}

1. T. Olcese, C. Pagella, ProgOrg Coat., 36 (231-241) (1999)

2. S. Duquesne, P. Bachelet, S. Bellayer, J Fire Sci, 31 (258-275) (2013)

3. H. M. Spencer Intumescent silicate compositions. Patent US no. 1847366A (1932)

4. V. Kiseleva, O. Zybina, SPbPU Week of Science, (140-142) (2016) (in Russian)

5. O. Zybina, M. Gravit, Y. Stein, IOP Conf. Ser: Earth and Environmental Science, 90 (1) (2017)

6. O. Zybina, M. Silnikov, A. Volkov, Defense Engineering Problems. Series 16. Technical means of combating terrorism, 1-2 (172-175) (2017)

7. O Nedryshkin, M Gravit, O Mukhamedzhanova, IOP Conference Series: Earth and Environmental Science 90 (1) (2017)

8. M Gravit, I Dmitriev, A Ishkov, IOP Conference Series: Earth and Environmental Science 90 (1) (2017)

9. M. Gravit, E. Golub, S. Antonov, Mag. Civ. Eng., 3 (86-94) (2018)

10. M. Gravit, O. Nedryshkin, O. Ogidan, Mag. Civ. Eng., 1 (38-46) (2018)

11. A. Lucherini, L. Giuliani, G. Jomaas, Fire Safety J., 95 (42-50) (2018)

12. T. Gong, Q. Xie, X. Huang, Fire Safety J., 95 (113-121) (2018)

13. O. Zybina, M. Gravit, A. Pizhurin, IOP Conf. Ser.: Earth and Environmental Science, 90 (1) (2017)

14. A. Ustinov, V. Lebedev, D. Orlova, A. Tomahova, I. Virolainen, SPbPU Week of Science (142-145) (2017) (in Russian)

15. A. Ustinov, R. Gavakhunova, O. Zybina, Modern Fireproof Materials and Technologies, (163-169) (2017) (in Russian)

16. A. Ustinov, O. Zybina, L. Tanklevsky, V. Lebedev, A. Andreev, E3S Web of Conferences, 33 (2018)

17. O. Nedryshkin, M. Gravit, A. Lyapin, V. Voronin, MATEC Web of Conferences, 86 (2016)

18. M. Gravit, O. Nedryshkin, O. Ogidan, Mag. Civ. Eng., 1 (38-46) (2018)

19. O. Nedryshkin, M. Gravit, K. Grabovyy, MATEC Web of Conferences, 193 (2018) 
20. GOST 30247 (2003) (in Russian)

21. BS EN $13501-1$ (2002)

22. GOST 53307 (2009) (in Russian)

23. NFP 92-505: Dripping test with electrical radiator, used for melting materials 24. GOST 51293-99 (2009) (in Russian) 